\title{
Gambaran makroskopik dan mikroskopik kandung kemih pada hewan coba postmortem
}

\author{
${ }^{1}$ Larisa M. Pontoh \\ ${ }^{2}$ Sonny J. R. Kalangi \\ ${ }^{2}$ Martha M. Kaseke
}

\author{
${ }^{1}$ Kandidat Skripsi Fakultas Kedokteran Universitas Sam Ratulangi Manado \\ ${ }^{2}$ Bagian Anatomi Histologi Fakultas Kedokteran Universitas Sam Ratulangi Manado \\ Email: larisa.pontoh@gmail.com
}

\begin{abstract}
The aim of this study was to obtain the microscopic and microscopic postmortem changes of urinary bladder in domestic pigs. This was a descriptive observational study. The observations were performed at several time intervals, as follows: 1, 2, 3, 4, 5, 6, 9, 12, 15, 18, $21,24,30,36,42$, and 48 hours postmortem. The macroscopic observation of urinary bladder showed that the organ color became darker at 2-3 hours postmortem, the consistency became soft at 24 hours postmortem, and the organ became flattened and longer at 24-30 hours postmortem. The microscopic changes were epithelial desquamation at 1 hour postmortem which was continued leaving a flat thin basal layer at 24 hours postmortem. Congestion was observed at 1 hour postmortem. Hydropic degeneration of the muscle layer began at 3 hours postmortem, and the layer became unidentified at 42 hours postmortem. Epithelial changes were hydropic degeneration, picnotic, and anuclear at 4 hours and were identified until 21 hours postmortem. Debris of necrotic epithelial cells was observed until 36-48 hours postmortem. Conclusion: The earliest macroscopic change started at 3 hours postmortem was the change in color. The earliest microscopic changes started at 1 hour postmortem were epithelial desquamation and congestion.
\end{abstract}

Keywords: macroscopic, microscopic, urinary bladder, postmortem

\begin{abstract}
Abstrak: Tujuan penelitian ini untuk mengetahui gambaran perubahan makroskopik dan mikroskopik kandung kemih hewan coba babi postmortem. Jenis penelitian ialah deskriptif observasional. Perubahan diamati pada beberapa interval waktu postmortem: 1 jam, 2 jam, 3 jam, 4 jam, 5 jam, 6 jam, 9 jam, 12 jam, 15 jam, 18 jam, 21 jam, 24 jam, 30 jam, 36 jam, 42 jam, dan 48 jam. Hasil pengamatan makroskopik mendapatkan perubahan warna kandug kemih menjadi lebih gelap dari 2 jam ke 3 jam postmortem, konsistensi berubah dari kenyal menjadi lunak sampai 24 jam postmortem, organ mengempis dan memanjang pada 24 jam sampai 30 jam postmortem. Perubahan mikroskopik berupa deskuamasi sejak 1 jam postmortem dan pada 24 jam postmortem tersisa epitel basal tipis dan rata. Kongesti terlihat sejak 1 jam postmortem. Degenerasi hidrofik pada lapisan otot sejak 3 jam postmortem sampai lapisan tersebut tidak jelas teramati 42 jam postmortem. Perubahan epitel berupa degenerasi hidrofik, inti piknotik, dan anukleus dimulai pada 4 jam postmortem dan terus berlanjut sampai 24 jam postmortem. Debris sel nekrosis terlihat pada 36 sampai 48 jam postmortem. Simpulan: Perubahan makroskopik mulai tampak pada 3 jam postmortem berupa perubahan warna. Perubahan mikroskopik mulai tampak pada 1 jam postmortem berupa deskuamasi epitel dan kongesti.
\end{abstract}

Kata kunci: makroskopik, mikroskopik, kandung kemih, postmortem 
Setelah kematian atau postmortem, tubuh mengalami proses perubahan oleh berbagai faktor yang memengaruhinya. Penetapan waktu kematian sebagai tugas seorang ahli forensik histopatologi, dilakukan dengan cara memahami perubahan postmortem interval (PMI). ${ }^{1,2}$

Terdapat banyak cara untuk menetapkan waktu kematian, antara lain dengan identifikasi gambaran perubahan organ (makroskopik) dan jaringan (mikroskopik) saat postmortem yang sangat berguna pada kasus dengan bagian tubuh yang tidak lengkap misalnya pada kasus mutilasi, akibat kecelakan, bencana alam, gigitan binatang buas dan sebagainya, bergantung pada sisa organ tubuh yang dapat dimanfaatkan untuk menentukan saat kematian. $^{3}$

Hasil penelitian Tomita menunjukkan terdapatnya perbedaan dalam kepekaan perubahan postmortem pada jaringanjaringan yang berbeda. Berbagai penelitian juga telah mengulas mengenai perubahan makroskopik dan mikroskopik sebagai penentu kematian pada beberapa organ. Walaupun demikian, masih terdapat berbagai kendala seperti banyak penelitian lebih terpusat pada satu jenis organ, belum bisa dilakukan penentuan evaluasi komparatif dari variasi rata-rata dekomposisi tubuh manusia. Penetapan waktu setelah kematian masih terus diteliti melalui studi perubahan degeneratif pada variasi tubuh manusia setiap interval yang berbeda oleh ahli forensik histopatologik di berbagai belahan dunia., ${ }^{4,5}$

Misteri bagi peneliti tentang perubahan sensitivitas postmortem khususnya pada jaringan kandung kemih mendorong Erman dan Veranic $^{6}$ menemukan suhu yang tepat untuk memperlambat autolisis sel-sel kandung kemih tikus yaitu suhu ruangan lebih lambat autolisisnya dari $37^{\circ} \mathrm{C}$ dan $1^{\circ} \mathrm{C}$. Erlandsson dan Munro ${ }^{7}$ mendapatkan pada gambaran postmortem epitel transisional kerapuhan terjadi pada 24 jam, serta gambaran perubahan postmortem pada hari ke-2, ke-3, hari ke-7 dan sampai tidak ditemukan sel lagi yaitu minggu ke-3.

Babi sebagai hewan coba tergolong mamalia yang lebih besar dari anjing dan tikus. Hewan ini dipergunakan dalam berbagai penelitian karena memiliki beberapa karakteristik struktur anatomi dan fisiologi yang sama dengan manusia dewasa. ${ }^{8}$

Penelitian tentang perubahan mikroskopik organ selama postmortem pada hewan coba babi telah banyak dilakukan di Bagian Anatomi Histologi Fakultas Kedokteran Universitas Sam Ratulangi yaitu antara lain: lambung, hepar, ginjal, jantung, kulit, otot skelet, ureter, dan usus besar selama 24 jam. ${ }^{9-16}$ Penelitian ini bertujuan untuk mendapatkan gambaran perubahan makroksopik dan mikroskopik kandung kemih selama 48 jam postmortem pada hewan coba.

\section{METODE PENELITIAN}

Jenis penelitian ialah deskriptif observasional yang dilakukan di Laboratorium Anatomi Histologi Fakultas Kedokteran Universitas Sam Ratulangi Manado dan Pusat Diagnostik Patologi Anatomi Manado. Hewan coba dua ekor babi domestik berat $\pm 20 \mathrm{~kg}$ dimamtikan dengan tusukan pada jantung dan waktu kematian dicatat saat hewan coba berhenti bernapas. Dokumentasi gambaran makroskopik kandung kemih diambil pada babi pertama dan pengambilan sampel untuk gambaran mikroskopik kandung kemih pada babi kedua dengan interval waktu 1 jam, 2 jam, 3 jam, 4 jam, 5 jam, 6 jam, 9 jam, 12 jam, 15 jam, 18 jam, 21 jam, 24 jam, 30 jam, 36 jam, 42 jam, dan 48 jam postmortem. Setiap sampel organ untuk pemeriksaan mikroskopik diambil pada suhu ruang laboratorium dan difiksasi dengan formalin $10 \%$. Sampel dilabel penomoran dan penamaan masing-masing berdasarkan waktu pengambilan dan diproses untuk pembuatan sediaan mikroskopik di Pusat Diagnostik Patologi Anatomi (PDPA) Manado. Sediaan diidentifikasi dengan mikroskop cahaya dan dibuat mikrofoto dengan optilab viewer.

Gambaran makroskopik yang diamati ialah perubahan warna, konsistensi, bentuk, 
ukuran, dan bau sedangkan gambaran mikroskopik yang diamati ialah deskuamasi epitel, kongesti, degenerasi hidrofik, tanda nekrosis sel (inti piknotik, kakrioreksis, dan kariolisis).

\section{HASIL PENELITIAN}

Makroskopik awal organ kandung kemih berwarna kemerahan, konsistensi kenyal, panjang $3,5 \mathrm{~cm}$ dan lebar $2,5 \mathrm{~cm}$, bentuk bulat telur. Bau amis mulai muncul pada 2 jam postmortem (Gambar 1A). Pada 3 jam postmortem, warna kandung kemih berubah menjadi gelap yang menetap sampai akhir penelitian (Gambar 1B). Pada 30 jam postmortem, terjadi perubahan bentuk menjadi memanjang, manifestasi pengurangan rentang lebar dari 30 jam sampai akhir penelitian menjadi $2-2,5 \mathrm{~cm}$ (Gambar 1C). Persentase perubahan makroskopik dapat dilihat pada Tabel 1.
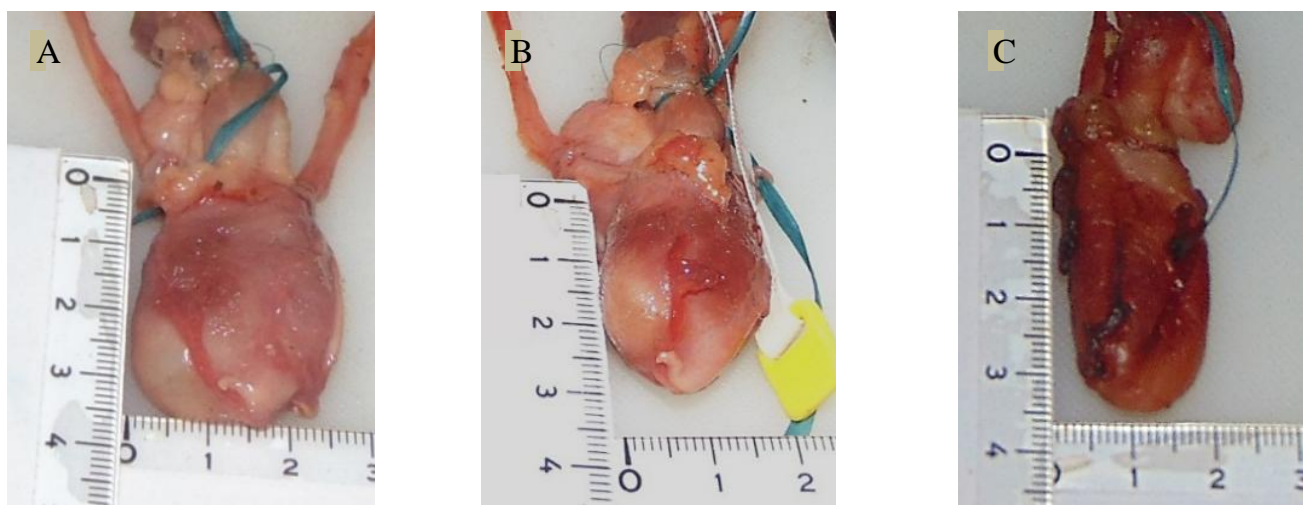

Gambar 1. Kandung kemih. A, 2 jam postmortem; B, 3 jam postmortem; C, 30 jam postmortem

Tabel 1. Perubahan warna, konsistnsi ukuran dan bau dari kandung kemih hewan coba dalam variasi waktu postmortem

\begin{tabular}{ccccc}
\hline Post-mortem & Warna & Konsistensi & Ukuran/bentuk & Bau \\
\hline 2 jam & - & - & - & - \\
3 jam & + & + & - & - \\
4 jam & + & + & - & - \\
5 jam & + & + & - & - \\
6 jam & + & ++ & - & - \\
9 jam & + & ++ & - & - \\
12 jam & + & +++ & - & - \\
15 jam & + & ++++ & - & - \\
18 jam & + & ++++ & - & - \\
21 jam & + & ++++ & - & - \\
24 jam & + & ++++ & + & - \\
30 jam & + & ++++ & + & - \\
36 jam & + & ++++ & + & - \\
42 jam & + & ++++ & + & - \\
48 jam & + & ++++ & & + \\
\hline
\end{tabular}

Keterangan:

(+) : Teridentifikasi

(-) : Tidak teridentifikasi

Perubahan mikroskopik yang paling awal berupa deskuamasi epitel pada 1 jam postmortem yang berlanjut sampai 24 jam postmortem sehingga tersisa lapisan basal. Pada 1 jam postmortem terdapat kongesti pada submukosa (Gambar 2A). Pada 3 jam 
postmortem, terjadi degenerasi hidrofik pada sel-sel lapisan otot, kongesti, dan terjadi pemisahan antara lapisan-lapisan jaringan mulai dari 1 jam sampai 42 jam postmortem (Gambar 2B). Pada 4 jam postmortem, sel-sel epitel mengalami degenerasi hidrofik, piknotik, dan anukleus yang bertambah dan meluas pada 24 jam postmortem (Gambar 2C). Pada 36 jam postmortem, terindentifikasi debris nekrosis dan lapisan epitel tersisa lapisan basal yang merata pada 42 jam postmortem. (Gambar 2D).

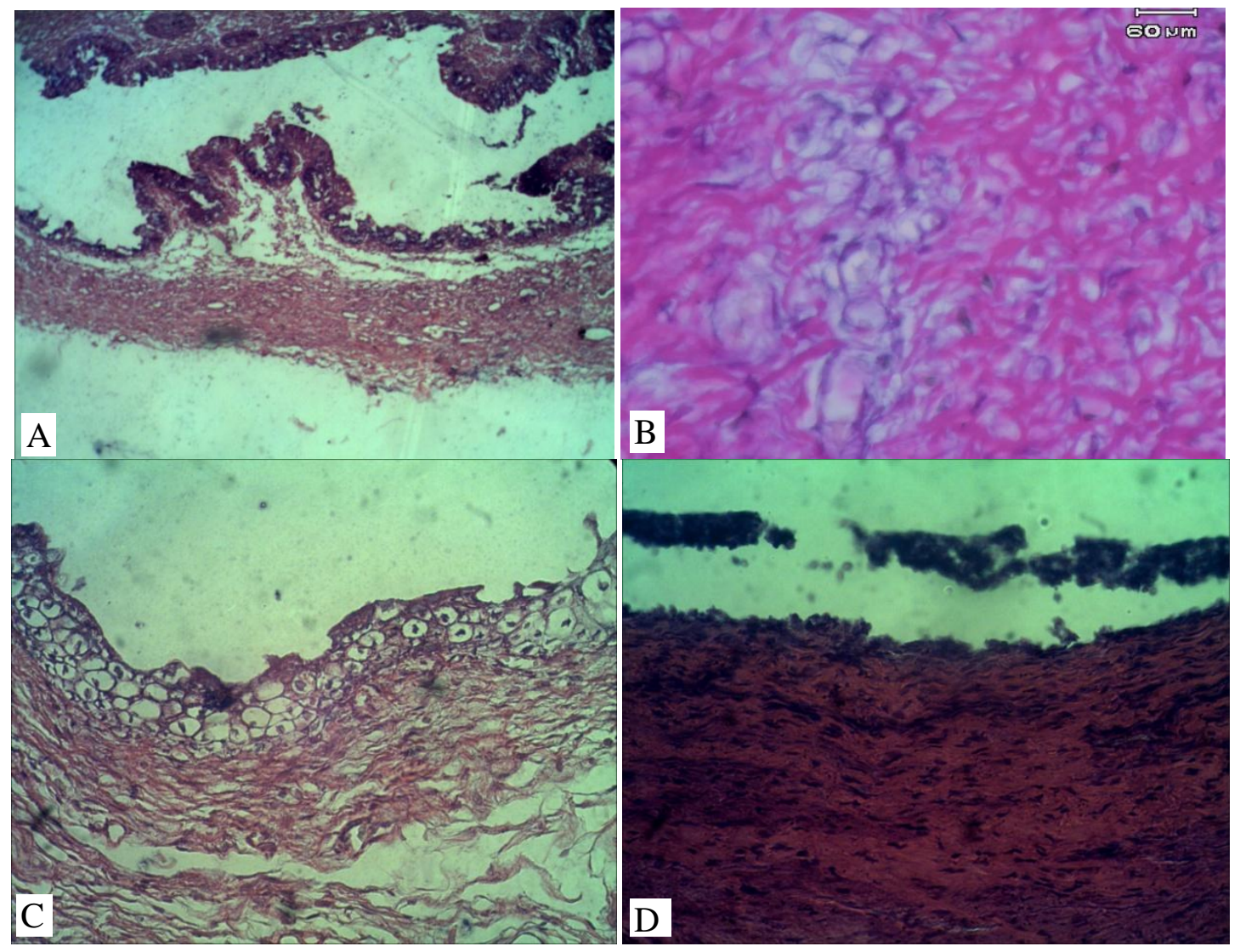

Gambar 2. A, Dinding kandung kemih 1 jam postmortem: deskuamasi mukosa, kongesti submukosa dan otot (100x); B, Lapisan otot 3 jam postmortem: degenerasi hidropik lapisan otot dapat diidentifikasi (400x); C, Kandung kemih hewan coba 4 jam postmortem: degenerasi hidropik mukosa, epitel anukleus, piknotik (400x); D, Lapisan mukosa 42 jam postmortem: mukosa dan epitel nekrosis dapat diidentifikasi (400x).

\section{BAHASAN}

Perubahan awal kematian ialah darah mulai terakumulasi dan lisis eritrosit dengan imbibisi jaringan lunak sekitar dari pelepasan $\mathrm{Hb}$, memberi perubahan makroskopik organ berwarna merah terang yang berubah menjadi gelap sebagai hasil dari kerusakan dan kerja gas $\mathrm{H}_{2} \mathrm{~S}$. Aktivitas bakteri terhadap hemoglobin yang sekaligus memberi bau amis pada bangkai yang tercium lebih kuat pada akhir penelitian. ${ }^{17-19}$
Deskuamasi terjadi pada 1 hari postmortem yaitu disfungsi kompleks taut disertai disfungsi hemidesmosom memberi celah akumulasi cairan (kongesti) pada submukosa dan terus berlanjut di berbagai tempat memisahkan lapisan-lapisan jaringan. ${ }^{20-22}$ Pada 1 jam postmortem, selsel terlihat homogen karena glikolisis anaerob menggantikan berkurangnya ATP yang berakibat akumulasi asam laktat yang meningkatkan $\mathrm{pH}$ sitoplasma. ${ }^{23}$

Perubahan mikroskopik degenerasi 
hidrofik dimulai pada 3 jam postmortem, terjadi karena kegagalan pompa ion energidependen pada plasma membran yang berlanjut dengan ketidak mampuan mempertahankan homeostasis cairan dan ion-ion. Hal ini berdampak pada makroskopik perubahan konsistensi organ berubah dari kenyal-lunak menjadi kenyalpadat dinding terasa lebih tebal antara 3-5 jam postmortem. Pada 4 jam postmortem, sel-sel terlihat heterogen sehingga nekrosis inti sudah dapat diidentifikasi sebagai tanda bahwa sel telah mengalami kematian. Hal ini karena kehancuran DNA dan kromatin yaitu warna basofil kromatin memudar (sel anuklear) akibat aktivitas DNAase enzim lisosom bocor karena influks $\mathrm{Ca}^{2+}$ merusak membran lisosom, aktif dalam kondisi $\mathrm{pH} 5$ karena asam laktat, ikatan eosin untuk denaturasi protein sitoplasma dan hilangnya basofil yang normalnya dalam RNA (ribonucleic acid). Berikutnya terjadi inti piknotik sebagai tanda awal nekrosis. Sesuai dengan penelitian sebelumnya, hilangnya nukleus pada sel mati terjadi antara 1-2 hari. ${ }^{7,23}$

Peningkatan konsistensi lunak terjadi bersamaan dengan penurunan kekenyalan organ sebagai manifestasi perubahan mikroskopik proses deskuamasi dan nekrosis yang akhirnya bersisa lapisan sel basal dari 5-12 jam postmortem berlanjut peningkatan konsistensi lunak organ yang pada mikroskopisnya, epitel bersisa lapisan basal pada 24 jam postmortem. Perubahan berlanjut dengan bentuk telur dari awalnya berubah karena berkurangnya ukuran lebar yang bervariasi dengan rentang lebar $2 \mathrm{~cm}$ $2,5 \mathrm{~cm}$, ke bentuk oblong dengan rentang lebar 1,8-2 $\mathrm{cm}$ pada 30 jam. Perubahan pada 30 jam ini berkolerasi dengan perubahan mikroskopik, tonjolan lapisan epitel basal mukosa merata dengan debris nekrosis terlihat diatasnya.

Perubahan konsistensi, ukuran dan bentuk organ terjadi karena proses deskuamasi awal, terjadi reduksi protein taut membran sel lisis karena hipoksia gagal sirkulasi, menurunkan ATP yang dibutuhkan oleh membran yang diperparah influks $\mathrm{Ca}^{2+}$ dari eksternal melalui membran rusak melepas enzim proteolitik lisosom berupa lipase, karbohidrases dan terutama protease dan hidrolase dengan enzim kateptik seperti kalpain lisosom menghilangkan pertahanan strukturstruktur dalam sel yaitu protein sitoplasma penyusun taut pada deskuamasi sebagai alasan utama mengapa jaringan melunak dan kepadatan menghilang. ${ }^{6,23}$ Perubahan mikroskopik autolisis menghasilkan nutrisi untuk bakteri saprofitik yang dilanjutkan proses putrefaksi. ${ }^{17-19}$

Pada 36 jam postmortem terlihat debris sel nekrosis diatas lapisan basal yang tersisa. Hal ini terjadi karena sel nekrosis menghilang mengalami degradasi menjadi asam lemak yang akan mengikat garam kalsium. ${ }^{23}$ Perubahan-perubahan nekrosis hanya teridentifikasi pada epitel sampai 48 jam walau jaringan ikat dan lapisan otot terjadi nekrosis seperti pada penelitian lain. ${ }^{7,24}$

Penelitian Kanwar pada ureter kadaver dengan pengambilan sampel pada waktu yang diacak dan suhu lingkungan yang diacak sehingga pemotongan dilakukan pada suhu-suhu jauh berbeda dan ekstrim, pada 4 jam 30 menit setelah kematian, dengan suhu $23,9^{\circ} \mathrm{C}$ dan $33,4^{\circ} \mathrm{C}$, kelembaban $75 \%$ dan $95 \%$ terdapat arsitektur epitel bertahan, retraksi dan disrupsi. Otot memperlihatkan gangguan arsitektur, mengecil, rusak, piknotik sel otot polos, dan tampak celah di antaranya. Inti mengisut juga mulai terjadi pada penelitian pada 5 jam postmortem suhu $18,1^{\circ} \mathrm{C}$ dan $34,6^{\circ} \mathrm{C}$, kelembaban $20 \%$ dan $42 \%$ tetapi terdapat inti yang mengelap. Sel epitel anukleus pada 8 jam 10 menit suhu $21,2^{\circ} \mathrm{C}$ dan $28,6^{\circ} \mathrm{C}$, kelembaban $47 \%$ dan $77 \%$, terdapat epitel arkitektur baru saja terganggu pada 10 jam 35 menit postmortem suhu $23,6^{\circ} \mathrm{C}$ dan $29,2^{\circ} \mathrm{C}$, kelembaban $86 \%$ dan $92 \%$, yang diartikan perubahan postmortem tergantung bukan hanya pada lamanya waktu kematian, tetapi juga besarnya rentang suhu ruangan. ${ }^{24}$

Hasil penelitian ini sesuai dengan penelitian Erlandsson dan Munro $^{7}$ bahwa proses terlepasnya epitel mukosa terjadi selama 2 hari. Penelitian dengan anjing 
pemburu sebagai hewan coba ini bersuhu $10,9^{\circ} \mathrm{C}-16,8^{\circ} \mathrm{C}$ dan kelembaban $34 \%-63 \%$.

Hasil identifikasi ultrastruktural dalam penelitian Erman dan Veranic ${ }^{6}$ pada 1 jam $37^{\circ} \mathrm{C}$ yaitu arsitektur utuh, kontak sel intemedia dan superfisial terpisah menuju ke pengisutan sel dan pada 2 jam terdapat proporsi deskuamasi yang tinggi pada sel suprfisial dan sel intermedia membengkak.

Pada umumnya terdapat variasi pada setiap hasil penelitian histologik postmortem walaupun menggunakan organ dan interval waktu yang sama karena ratarata autolisis organ dan jaringan bervariasi bergantung suhu ruangan beserta selisihnya, ukuran tubuh, status nutrisi, organ yang memiliki flora bakteri, sekresi enzim, sifat yang lembab dan pengaruh substrat seperti pankreas, keadaan sebelum kematian, bulu hewan dan spesies hewan seperti pada spesies babi memiliki otot yang lembut dan lembab serta hipertermia antemortem yang menyebabkan pireksia memberikan panas yang menghabiskan cairan. ${ }^{6,7,17-19,23}$

\section{SIMPULAN}

Perubahan makroskopik mulai tampak pada 3 jam postmortem berupa perubahan warna. Perubahan mikroskopik mulai tampak pada 1 jam postmortem berupa deskuamasi epitel dan kongesti.

\section{UCAPAN TERIMA KASIH}

Ucapan terima kasih ditujukan kepada dr. Shane H. Ticoalu, Mkes, AIFO, dr. Poppy M. Lintong, $\operatorname{SpPA}(\mathrm{K})$, dan semua pihak secara langsung maupun tidak langsung yang telah membantu pada proses penelitian.

\section{DAFTAR PUSTAKA}

1. Budiyanto A, Widiatmaka $W$, Sudiono $S$, Mun'im WA, Sidhi, Hertian S, et al. Ilmu Kedokteran Forensik. Jakarta: FKUI, 1997; p. 25.

2. Pinheiro J. Introduction to forensic medicine and pathology. 2006. [cited 2016 Sep 18]. Available from: http://www.springer.com/978-1-58829824-9.
3. Kushwaha V, Yadav M, Srivastava AK, Agarwal A. Time since death from degenerative changes in the kidney. $\mathbf{J}$ Indian Acad Forensic Med. 2009;32:37.

4. Roul B, Goyal M, Gautam D. Sequential postmortem histological changes in human adrenal gland up to thirteen hour \&thirty minutes post mortem interval. Int $\mathbf{J}$ Advanced Res. 2015;3:1138.

5. Tomita Y, Nihira M, Ohno Y, Sato S. Ultrastrctural changes during in situ early postmortem autolysis in kidney, pancreas, liver, heart, and skeletal muscle of rats. Legal Medicine. 2004;25-31.

6. Erman A, Veranic P. Time- and temperaturedependent autolysis of urinary bladder epithelium during ex vivo preservation. Protoplasma. 2011;248:541-50.

7. Erlandsson M, Munro R. Estimation of the post-mortem interval in beagle dogs. Science and Justice. 2007;47:150-4

8. Swindle MM, Makin A, Herron AJ, Clubb FJ, Frazier KS. Swine as models inbiomedical research and toxicology testing. Vet Pathol. 2012;49:344-56.

9. Lilingan M, Kalangi SJR, Wangko S. Gambaran histologik gaster pada hewan coba selama 24 jam postmortem. eBm. 2016;4(1).

10. Pualillin NK, Kalangi SJR, Wangko S. Gambaran histologik hepar pada hewan coba selama 24 jam postmortem. JBM. 2014;6:2.

11. Rahmadana B, Kalangi SJR, Wangko S. Gambaranhistologik ginjal pada hewan coba selama24 jam postmortem. eBm. 2014;2:2

12. Ubruangge $T$, Wangko $S$, Kalangi SJR. Gambaran histologik otot jantung pada hewan coba postmortem. $\mathrm{eBm}$. 2016;4(2).

13. Abeng KA. Gambaran struktur kulit hewan coba pada beberapa interval waktu postmortem.eBm. 2016;4(1).

14. Savalina DNS, Ticoalu SHR, Wangko S. Gambaran makroskopik dan mikroskopik ureter pada hewan coba postmortem. 2016;4:2

15. Nelwan GB, Wangko S, Pasiak TF. Gambaran makroskopik dan mikroskopik otot skelet pada hewan coba postmortem. eBm. 2016;4(2).

16. Lapian C, Wangko S, Wongkar D. 
Perubahan histologik pada usus besar hewan coba postmortem. eBm. 2016;4(2).

17. Somvanshi R. Autolytic changes. In: Somvanshi R, Rao JR, editors. Necropsy Tchniques and Necropsy Conference Manual. 2009. [cited 2016 sep 30]. Available from: http://krishikosh.egranth.ac.in/bitstrea m/1/2057317/1/0098_NECROPSY\%2 OTECHNIQUE\%20AND\%20NECRO PSY\%20CONFERENCE\%20MANU AL.pdf

18. Goff ML. Early postmortem changes and stages of decomposition. In: Amendt J, Goff ML, Campobasso CP, Grassberger M, editors. Current Concepts in Forensic Entomology. 2010. [cited 2016 Ag 27]. Available from:

http://www.springer.com/us/book/978 1402096839
19. Dimaio VJ, Dimaio D. Forensic Pathology (2nd ed). New York: CRC press, 2001; p. 52-3.

20. Mescher AL. Junqueira's Basic Histology Text \& Atlas (13th ed). United States: McGraw-Hill Education, 2013.

21. Gartner LP, Hiatt JL. Buku Ajar Berwarna Histologi (3rd ed). Singapura: Elsevier, 2014.

22. Larsson L. Cytology. In: Eurell JA, Frappier BL, editors. Dellman's Textbook of Veterinary Histology (6th ed). Danver: Blackwell Publishing, 2006.

23. Kumar V, Abbas AK, Aster JC. Buku Ajar Patologi Robbins (9th ed). Singapore: Elsevier, 2015.

24. Kanwar Y, Goyal M, Roul B. Postmortem histological sequential changes in human renal vessels and pelvis of up to thirteen hours post mortem interval. Int J Advanced Res. 2015;3:1167-81. 